\title{
Protein Enrichment of Irish potato (Solanium tuberosium) peels through Solid Substrate Fermentation by Saccharomyces cerevisiae and Aspergillus Niger
}

\author{
Akintomide, M. J. ${ }^{1}$ Antai, S. P. ${ }^{2}$ \\ ${ }^{1,2}$ Department of Microbiology, University of Calabar P.M.B. 1115, Calabar, Cross River State Nigeria
}

\begin{abstract}
Flour prepared from dried potato peels were inoculated with pure strains of either Aspergillus niger or Saccharomyces cerevisiae and then left to ferment for seven days. Chemical analysis of the fermented peel mash revealed a significant $(P<0.05)$ increase in the crude protein content $(13.62 \%)$ of the potato peel mash when compared with the unfermented potato peel (10.50\%). The result also shows that fermentation increased significantly the crude protein, ash, lipid and fibre contents of the fermented potato peel mash, while a decrease in carbohydrate was observed. Moisture concentration of $125 \%$, temperature of $30^{\circ} \mathrm{C}$ and $25^{\circ} \mathrm{C}$ and a $\mathrm{pH}$ of 3.5 and 5.5 were found to be optimum for the growth of A. niger and S. cerevisiae on the mash. Increase in all mass resulting from the growth of the two fungi contributed to the resultant increase in the crude protein content of the fermented mash. The fermented peels could therefore be a good source of cheap protein enriched feed.
\end{abstract}

Keywords - Potato peels; Fermentation; Crude Protein content; Fungi.

\section{Introduction}

The white or Irish potato (Solanum tuberosum), also called the "earth apple", is grown in nearly all parts of the tropical and subtropical world and in warmer areas of the temperate regions. It has remained for centuries an important staple for many tropical communities [1]. Solanum tuberosum is the fourth largest yielding crop plant in the world, producing nearly 300 million metric tons of tubers per annum [2]. The potato peels are rich in phytonutrients [3], carbohydrates, high in starch (8-28\%) but with only about 1-4\% protein. Anon [4] reported that potato starch is a large-grained starch containing $25 \%$ amylose and $73 \%$ amylopectin and high phosphate content. A large amount of potato peels are discarded during processing for chips by many industries. These peels constitute a potential source of livestock feed ingredient. The major limitation in the use of potato peels for livestock feeding is its low protein content. Protein enrichment of potato peels through inexpensive means is therefore desirable.

Fermentation is one of the oldest and most widespread methods of preserving food. The fermentation of staples contributes significantly to food security by increasing the range of raw materials that can be used for the production of edible food products [5]. Fermentation enhances the nutrient content of foods through the biosynthesis of proteins, vitamins and essential amino acids. It also enhances micronutrient bioavailability and aids in degrading anti-nutritional factors [6].

Fungal fermentation has been identified as an inexpensive tool for increasing the protein level of substrates in a solid media fermentation technique. This study therefore sought to investigate how to increase the protein level of flour made from potato peels during solid state fermentation with Aspergillus niger and Saccharomyces cerevisiae.

\subsection{Microorganisms}

II. Materials And Methods

Local isolate of $A$. niger were obtained from decaying yam (Dioscorea rotundata) tuber and maintained on potato dextrose agar (PDA) slants at $28 \pm 2^{\circ} \mathrm{C}$. The subculturing was done once in a fortnight. Commercial dried baker's yeast (Saccharomyces cerevisiae) was purchased from Watt market in Calabar metropolis. The yeast was reactivated with $100 \mathrm{ml}$ of warm $\left(50^{\circ} \mathrm{C}\right)$ sterile distilled water and maintained on slants of sterile Sabouraud dextrose agar (SDA) medium after subculturing. The inoculated slants were allowed to incubate at $30^{\circ} \mathrm{C}$ for two days after which they were stored at $4^{\circ} \mathrm{C}$ and sub-cultured once every fortnight. Spore suspensions were prepared in five $\mathrm{ml}$ sterile distilled water.

\subsection{Substrate Preparation}

The potato peels used in this study were obtained from fast food facilities in Calabar, Cross-River State. The peels were washed thoroughly with sterile distilled water, cut into tiny bits and dried in an oven at 60${ }^{\circ} \mathrm{C}$ for 48 hours. The dried peels were milled in a hammer mill (Thomas Wiley Mill, Model ED-5, USA) and subsequently sieved with a $0.5 \mathrm{~mm}$ screen mesh. The sieved flour was transferred into $250 \mathrm{ml}$ Erlenmeyer flasks 
and autoclaved at $121^{\circ} \mathrm{C}$ for 15 minutes. They were then cooled to room temperature and subjected to chemical analysis to determine their proximate composition.

\subsection{Fermentation of Substrates}

Twenty grams of the dried sieved sample was weighed out into $250 \mathrm{ml}$ Erlenmeyer flasks in triplicates, and moistened by adding $25 \mathrm{ml}$ of sterile distilled water. The flasks were plugged with sterile cotton wool wrapped in aluminum foil and the mash was left to ferment for seven days. The mash was then dried to a constant weight. Some quantity was chemically analysed while the remainder was stored for other experiments.

\subsection{Preparation of Inoculum}

Aspergillus niger inoculum was prepared from fresh mature (three to five days old) cultures grown on PDA slants. The spores from PDA slants were covered with $5 \mathrm{ml}$ of sterile distilled water and $0.2 \%$ Tween 80 was added to facilitate the preparation of the fungal inoculum. The colonies were carefully rubbed with a sterile loop; the isolates were then shaken vigorously for 15 seconds and then transferred to a sterile tube. Saccharomyces cerevisiae inoculum was prepared from stock vials by subculturing a loopful onto SDA plates. Five colonies were picked from 48 hours-old cultures and suspended in $5 \mathrm{ml}$ of sterile $0.85 \%$ saline. The resulting suspension was shaken vigorously for 15 seconds and then transferred to a sterile tube. All suspensions were quantified by plating on PDA plate for the fungi and on SDA plate for the yeast. Five serial 10-fold dilutions of each inoculum suspension were performed in sterile distilled water, and a $10 \mu \mathrm{l}$ of each portion of each dilution was spread over the surface of the agar plates with a sterile glass rod. The plates were incubated at $30^{\circ} \mathrm{C}$ and were observed daily for the presence of growth. The colonies were counted with an electric colony counter as soon as possible after the observation of visible growth.

\subsection{Determination of Optimum Conditions For Fermentation of Mash}

Procedures were as described above but the mineral salt solution used was adjusted to different $\mathrm{pH}$ levels of 3.5, 4.0, 5.5 and 6.0. The mash samples were incubated at varying temperatures of $25,30,35$ and $40^{\circ} \mathrm{C}$ respectively. The quantity of the mineral salt solutions added were adjusted to moisture levels of 50, 70, 100 and $125 \%$ moisture $(\mathrm{v} / \mathrm{w})$ to determine the optimum moisture level needed for fermentation of the mash.

\subsection{Fermentation of Potato Peel Mash Inoculated with Organisms:}

The potato peel (flour) was weighed out in $20 \mathrm{~g}$ quantities into $250 \mathrm{ml}$ Erlenmeyer flasks and $25 \mathrm{ml}$ of sterile mineral solution was added to each container to moisten the mash. The flasks were then autoclaved for 15 min at $121^{\circ} \mathrm{C}$. After sterilization, the flasks were then aseptically inoculated with two ( $\left.2 \mathrm{ml}\right)$ of each active inoculum $\left(3 \times 10^{9} \mathrm{cfu}^{-\mathrm{ml}^{-1}}\right)$, properly labeled and plugged with sterile cotton wool. The flasks were left to ferment at $28 \pm 2^{\circ} \mathrm{C}$ for 7 days. At the end of the fermentation period, the mash was dried and subjected to chemical analysis.

\subsection{Compositional Analysis}

The nutritional composition (ash, crude lipid and crude fiber) of the fungi/yeast fermented potato product was evaluated using the standard AOAC method [7]. The protein content was determined using the microkjeldhal method ( $\mathrm{N}$ x 6.25) while the carbohydrate content was estimated by the difference method.

\subsection{Statistical Analysis}

The results are presented as the mean standard values of three replicates each. A one-way analysis of variance (ANOVA) and the Least Significance Difference were carried out. Significance was accepted at P < 0.05 .

\section{Results}

The chemical analysis of the unfermented and fermented mash prepared from potato peels (Solanum tuberosum) revealed a significant increase $(\mathrm{P}<0.05)$ in the protein content from $10.50 \%$ (unfermented) to $13.62 \%$ (fermented) after seven days fermentation (Table 1).

Fig 1 shows the crude protein produced by A. niger or S. cerevisiae growing on potato peel mash which had been adjusted to contain different moisture levels. The highest amount of crude protein was obtained when $20 \mathrm{~g}$ of mash was supplemented with $25 \mathrm{ml}$ of water representing $125 \%$ moisture level.

The effects of $\mathrm{pH}$ on the protein yield of potato peel mash fermented by A. niger or S. cerevisiae are presented in Fig 2. While A. niger generated maximum crude protein yield of $15.01 \%$ at $\mathrm{pH} 3.5$, S. cerevisiae yielded its maximum crude protein level of $15.27 \%$ at $\mathrm{pH}$ 5.5. 
The percentage crude protein yields of potato peel mash inoculated with A. niger or S. cerevisiae and fermented at varying temperatures are presented in Fig 3. A temperature of $30{ }^{\circ} \mathrm{C}$ and $25^{\circ} \mathrm{C}$ gave the highest crude protein levels of $13.35 \%$ and $14.17 \%$ respectively.

Fermentation of the substrates with moisture levels of $125 \%$, at incubation temperatures of $30^{\circ} \mathrm{C}$ and $25^{\circ} \mathrm{C}$ and with $\mathrm{pH}$ of each substrate adjusted to 3.5 and 5.5 respectively for A. niger and S. cerevisiae resulted in high growth rate of the organisms. Considerable cell mass was generated at these fermentation conditions as depicted by the further increase in the crude protein content with A. niger yielding $15.68 \%$ and S. cerevisiae yielding $18.62 \%$ respectively (Table 2 ).

\section{Discussion}

The results obtained from this study revealed that fermentation can bring about desirable changes in the nutrient composition of potato peels. From this study, both fungi showed potential to increase the protein content of the potato peel mash. The yeast S. cerevisiae demonstrated the best ability to enrich the peel mashes in seven days. The results obtained for A. niger are comparable to those of [8] who reported similar findings using sweet potato peels in solid state fermentation.

There was an increase in the protein content compared to the unfermented peel from $10.50 \%$ to $15.68 \%$ when fermented with A. niger. Also the peels when fermented with $S$. cerevisiae had an improvement to $18.62 \%$. This implied that the fungi and yeast had significant $(\mathrm{P}<0.05)$ effect on the protein content. The increase in the crude protein observed could be attributed to the additional crude protein (extracellular enzymes) such as amylases produced by the fungal mycelia [9][10][11][12] and thus secreted into the fermenting mash in an attempt to make use of the starches as a carbon source [13].

Furthermore, increase in the growth and proliferation of the microorganisms in the fermenting potato peel mash may possibly account for the apparent increase in the protein content of the fermented peel mash [14] [15]. Similar results have been reported using sweet potato in solid state fermentation [8][16].

An optimum temperature and $\mathrm{pH}$ range of $25^{\circ} \mathrm{C}$ and 5.5 respectively supported the highest crude protein formation when S. cerevisiae was grown on the potato peel mashes. This finding is in agreement with that of [17] who reported a temperature range between $25^{\circ} \mathrm{C}$ and $30^{\circ} \mathrm{C}$ to be favorable for the growth of most yeast. Similar findings were also reported by [14]. This observation further confirms that the increase in crude proteins observed is as a result of an increase in cell mass generated by the organism. A temperature range of $30^{\circ} \mathrm{C}$ was observed to support the highest crude protein formation in the case of A. niger, when the potato peel mash was fermented. This finding agrees with that of [18] who reported an optimum temperature of $30^{\circ} \mathrm{C}$ for $A$. niger. This temperature has also been reported to support extracellular enzyme production during the organism's growth [19].

The levels of moisture concentration were found to affect crude protein yields by both microorganisms. The lowest moisture concentration (50\%) supported the production of the least crude protein, whereas the highest moisture concentration (125\%) investigated supported the formation of the highest amount of crude protein. These results agrees with the reports of [20] who stated that maximal production of microbial protein required certain amount of moisture in order to render the contents of the substrate soluble for the fungi to assimilate and grow.

\section{Conclusion}

The results obtained in this study have shown that growing of fungi and yeast on potato peel mash can greatly enrich its protein content. In view of this significant protein yield increase, this by-product could be a good supplement in compounding animal feed provided that it is acceptable and highly digestible.

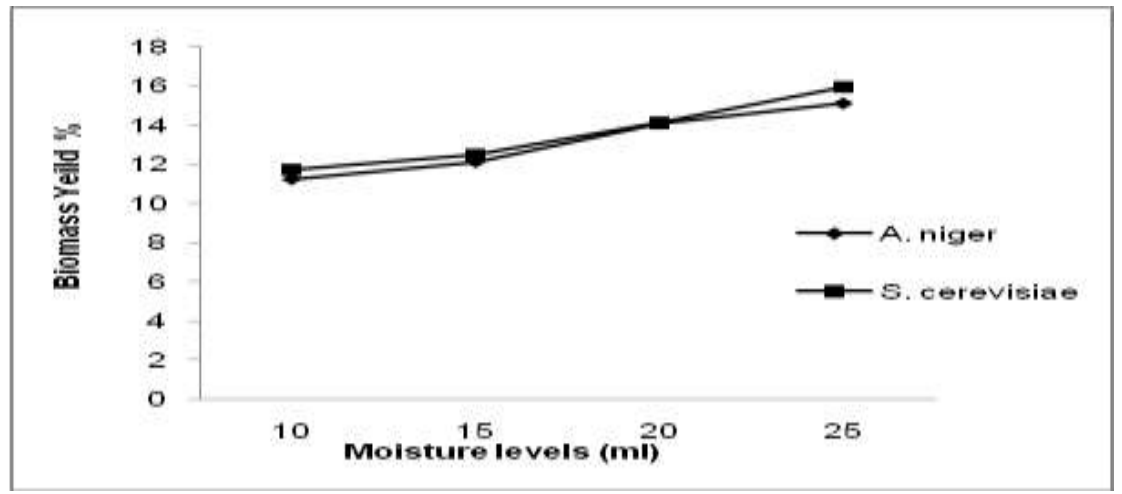

Figure 1. Effect of moisture levels on the crude protein yield of A. niger and S. cerevisiae on potato peel mash after fermentation 


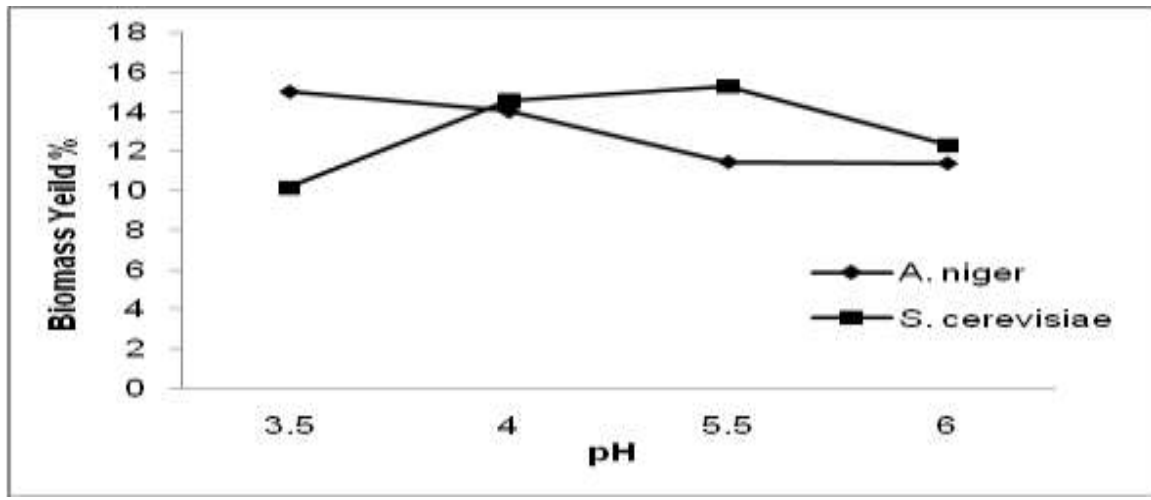

Figure 2. Crude protein yields resulting from the growth of A. niger and S. cerevisiae on potato peel mash adjusted to different $\mathrm{pH}$ levels

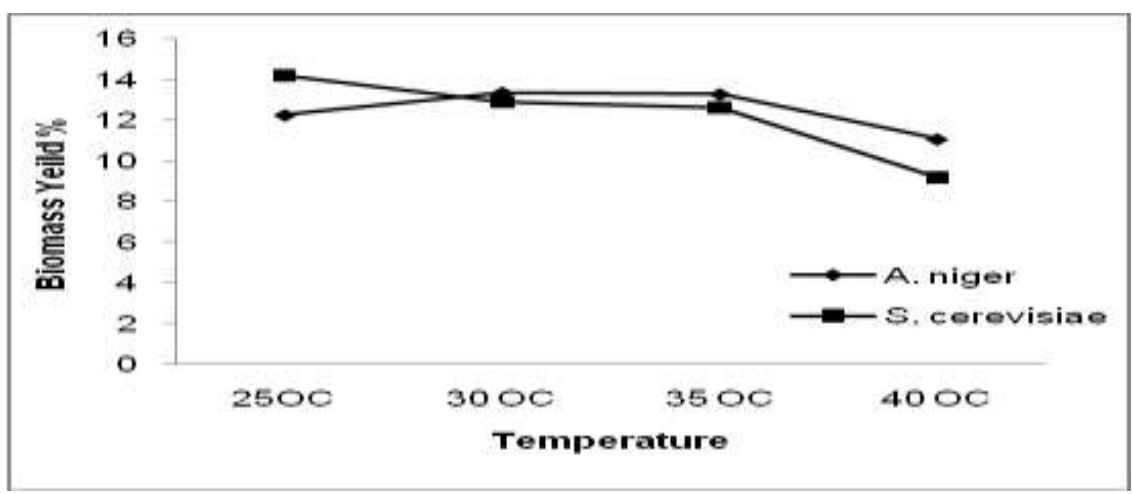

Figure 3. Crude protein yields resulting from the growth of A. niger and S. cerevisiae on mash prepared from potato peels and incubated at different temperatures

Table 1: Proximate compositions of potato peel mash samples after processing

\begin{tabular}{lll}
\hline Nutrients (\%) & Unfermented & Fermented \\
\hline Crude Protein & $10.50 \pm 0.1$ & $13.62 \pm 1.3$ \\
Crude Lipid & $1.32 \pm 0.2$ & $0.48 \pm 0.5$ \\
Crude Fiber & $6.20 \pm 0.2$ & $8.75 \pm 0.3$ \\
Carbohydrate & $76.65 \pm 0.2$ & $69.78 \pm 0.1$ \\
Ash & $5.33 \pm 0.6$ & $7.37 \pm 0.4$ \\
\hline
\end{tabular}

Values are mean \pm standard deviation, based on three replicate values

Table 2: Chemical compositions of potato peel mash inoculated with A. niger and S. cerevisiae and fermented

\begin{tabular}{lll}
\multicolumn{2}{c}{ for } & \\
\hline & Mash inoculated with & \\
\cline { 2 - 3 } Nutrients $(\%)$ & A. niger & S. cerevisiae \\
\hline Crude Protein & $15.68 \pm 0.2$ & $18.62 \pm 1.3$ \\
Crude Lipid & $0.96 \pm 0.4$ & $1.42 \pm 0.2$ \\
Crude Fiber & $10.25 \pm 1.3$ & $8.50 \pm 1.1$ \\
Carbohydrate & $64.85 \pm 2.5$ & $63.48 \pm 0.1$ \\
Ash & $8.26 \pm 0.5$ & $7.98 \quad 0.5$ \\
\hline
\end{tabular}

Values are mean \pm standard deviation, based on three replicate values. 


\section{References}

[1] A.A. Ogunjobi, B.C. Adebayo-Tayo, and A. A. Ogunshe, Microbiological, proximate analysis and sensory evaluation of processed Irish potato fermented in brine solution, African Journal of Biotechnology, 4(12), 2005, 1409-1412.

[2] A. Jones, P. D. Dukes, and J.M. Schalk, Breeding Vegetable Crops, in M. J. Bassett (Ed.) Sweet Potato Breeding (Westport, Connecticut, 1986) 1- 35.

[3] C. Brown, Breeding for Potato Nutrition Enhancement, American Journal of Potato Research, 81(1), 2007, $335-339$.

[4] Anon. International potato center. Annual Report, Lima, Peru, 1985, 23.

[5] S.R. Adewusi, T.V. Ojumu, and O.S. Falade, The effects of processing on total organic acids content and mineral availability of simulated cassava-vegetable diets. Plant Foods for Human Nutrition, 53(4), 1999, 369-380.

[6] S.C. Achinewhu, L.I. Barber, and I.O. Ijeoma, Physicochemical properties and garification (garri yield) of selected cassava cultivars in Rivers State, Nigeria. Plant Foods for Human Nutrition, 52(2), 1998, 133-140.

[7] AOAC. Official Methods of Analysis. $15^{\text {th }}$ ed. AOAC, Association of Official Analytical Chemists; (Washington, DC, 1990).

[8] O.A. Abu, Biochemical characteristics and utilization of processed sweet potato Legume batata (L) LAM for rabbit feeding, doctoral diss., University of Ibadan Ibadan, Nigeria, 1997

[9] A.L. Leninger, Bioenergetics and Metabolism, Principles of Biochemistry, 2 (New Delhi: CBS Publisher and Distributors, 1987) 313-356.

[10] N. Okafor, and A.O. Ejiofor, Rapid detoxification of cassava mash by a yeast simultaneously producing linamarase and amylase. Process Biochemistry, 25(3), 1990, 82-86.

[11] A.A. Akindahunsi, G. Oboh, A.A. Oshodi, Effect of fermenting cassava with Rhizopus oryzae on the chemical composition of its flour and garri. Rivista Italiana Delle Sostanze Grasse, 76(10), 1999, 437- 440.

[12] G. Oboh, and C.A. Elusiyan, Changes in the nutrient and anti-nutrient content of micro-fungi fermented cassava flour produced from low- and medium-cyanide variety of cassava tubers. African Journal of Biotechnology, 6(18), 2007, $2150-2157$.

[13] M. Raimbault, General and microbiological aspects of solid state fermentation. Electronic Journal of Biotechnology, 1(3), 1998, 34.

[14] S.P. Antai, and P.M. Mbongo, Utilization of cassava peels as substrates for crude protein formation. Plant Foods for Human Nutrition, 46(4), 1994, 345-351.

[15] G. Oboh, A.A. Akindahunsi, and A.A. Oshodi, Nutrient and antinutrients content of Aspergillus Niger fermented cassava products (flour and garri). Journal of Food Compound and Analysis, 15(5), 2002, 617 - 622.

[16] O.A. Abu, G.B. Oguntimein, and O.O. Tewe, Protein enrichment of sweet potato by solid state fermentation using four monoculture fungi. Nigerian Journal of Biotechnology, 9(1), 1998, 1- 4.

[17] I. Campbell, and J.H. Duffus, Culture, storage, isolation and identification of yeasts, in I. Campbell, and J.H. Duffus (Ed.), Yeasts: A practical approach (Oxford, England; Washington, DC, IRL Press, 1988) 1-15.

[18] A. Astoreca, C. Magnoli, M.L. Ramirez, M. Combina, and A. Dalcero, Water activity and temperature effects on growth of Aspergillus niger, A. awamori and A. carbonarius isolated from different substrates in Argentina. International Journal of Food Microbiology, 119(3), 2007, 314-318.

[19] A.V.K. Gupta, D.R.M. Gupta, and L.P. Yadava, Production and Characterization of $\alpha$-Amylase from Aspergillus niger. Biotechnology, 7(3), 2008, $551-556$.

[20] S.S. Kahlon, and M. Arora, Utilization of waste potato peels to produce fungal protein, Journal of Research, 24(2), 1987, 272-280. 